\title{
THE INFLUENCE OF TEMPERATURE CHANGES IN ACTIVATED SLUDGE PROCESSES ON IBUPROFEN REMOVAL EFFICIENCY
}

\author{
WPLYW ZMIAN TEMPERATURY W PROCESACH OSADU CZYNNEGO \\ NA EFEKTYWNOŚĆ USUWANIA IBUPROFENU
}

\begin{abstract}
The article presents results regarding the ibuprofen reduction rate at three various temperature values $\left(8,18\right.$ and $28{ }^{\circ} \mathrm{C}$ ) which were conducted using a static test in accordance with the PN-C-04645 'Water and wastewater. Evaluation of partial biodegradation of anionic and non-ionic surface active substances. Initial test' standard. A single study cycle including the analysis of ibuprofen degradation rate in specific temperature variants lasted $24 \mathrm{~h}$. The activated sludge for tests was obtained from the aeration zone of a bioreactor localized in the Central Wastewater Treatment Plant in Poznan City (Poland), which was used for inoculation $\left(1 \mathrm{~g} / \mathrm{dm}^{3}\right)$ of sterile samples with the medium and ibuprofen $\left(10 \mathrm{mg} / \mathrm{dm}^{3}\right)$ after appropriate pre-treatment (intense aeration for $\left.5 \mathrm{~h}\right)$. The analysis procedure included the separation and concentration of analytes from biodegradation samples by means of solid phase extraction (SPE) and subsequent determination with high performance liquid chromatography coupled with mass spectrometry (LC-MS/MS) using an UltiMate 3000 RSLC liquid chromatogram (Dionex, USA) with a tandem API 4000 QTRAP mass spectrometer (Biosystem, MDS Sciex, USA). Both literature review as well as the conducted initial studies confirmed that the removal of ibuprofen proceeds more rapidly at higher temperature values. A higher retention rate also enhanced the reduction of ibuprofen concentration. A decrease of its concentration was observed after $24 \mathrm{~h}$, which reached 40 and $50 \%$ for temperature values of 8 and $18{ }^{\circ} \mathrm{C}$, accordingly, whereas the highest reduction by approx. $65 \%$ was noted at $28^{\circ} \mathrm{C}$.
\end{abstract}

Keywords: activated sludge, $\mathrm{COD}$, ibuprofen, $\mathrm{pH}$, statistical test, temperature

\section{Introduction}

The pharmaceutical market is one of the most rapidly expanding branches of the industry due to a constantly increasing demand for the offered products. The amount of produced pharmaceuticals is correlated with the amount of medicinal substances introduced

\footnotetext{
${ }^{1}$ Institute of Chemistry and Technical Electrochemistry, Poznan University of Technology, ul. Berdychowo 4, 61-131 Poznań, Poland, phone +48 61665 2015, email: joanna.zembrzuska@put.poznan.pl

${ }^{2}$ Institute of Environmental Engineering, Poznan University of Technology, ul. Berdychowo 4, 61-131 Poznań, Poland, phone +48 61665 3496, fax +48 61665 2439, email: izabela.kruszelnicka@ @ut.poznan.pl

*Corresponding authors: izabela.kruszelnicka@put.poznan.pl,joanna.zembrzuska@put.poznan.pl
} 
into the environment. Regardless of the type of medication, its biodegradation pathway typically occurs via the same mechanism. After administration, the medication releases the active substance which is responsible for the therapeutic effect, which is then subjected to slow decomposition. The active substance and its metabolites are removed from the organism with faeces and urine, which enter into municipal wastewater and are transported into wastewater treatment plants. They enter the aquatic environment due to incomplete biodegradation in wastewater treatment plants or as a result of direct discharge to water, mainly surface water [1-3]. The dump of outdated drugs is another source of pharmaceutical pollutants. Additionally, breeding ponds and animal farms are also a notable threat to surface and ground waters due to the excessive application of pharmaceuticals (such as antibiotics) in order to prevent infections and provide protection from infectious pathogens $[4,5]$. The first studies focused on the monitoring of the presence of drugs in the aquatic environment were carried out by Terens in Germany in the early 90's [4, 5]. Other European countries as well as South America soon followed. The observations of surface water in terms of pharmaceutical content were later modified to include the control of wastewater at the inlet and outlet of the wastewater treatment plants. These studies confirmed the presence of different groups of drugs at concentrations ranging from $\mathrm{ng} / \mathrm{dm}^{3}$ to $\mu \mathrm{g} / \mathrm{dm}^{3}$ [6-8]. The issue associated with the presence of drugs in wastewater and water currently applies to the whole globe.

Studies regarding wastewater quality show that the concentration of ibuprofen in wastewater is the highest among drugs which belong to the group of analgestics [1]. Its high concentration in wastewater results from the fact that it is one of the most commonly purchased drugs among a broad list of pharmaceuticals available without prescription and for an affordable price. Due to the increasing consumption of ibuprofen and its incomplete biodegradation in wastewater treatment plants, this drug enters surface water. Numerous publications [9-11] indicate that the presence of non-steroidal anti-inflammatory drugs in mixtures with other pharmaceutical substances increases their toxicity. Ibuprofen mixed with acetylsalicylic acid, naproxen and diclofenac is characterized by a notably higher toxicity towards Daphnia magna compared to its toxicity as a pure substance [12]. This issue was also noted by the European Committee, which included ibuprofen, diclofenac and etynyloestriaol in the list of drugs which require the determination of safe input limits as part of expected changes to the Water Directive from 2013 [13]. This, in addition to the increasing social anxiety associated with the negative effects caused by the presence of drugs in the aquatic environment, results in a need to search for efficient methods of elimination of such substances. However, the implementation of technological solutions which would allow to remove such compounds is limited due to a lack of regulations which impose the necessity to reduce the amount of drugs in wastewater or water intended for human consumption. Despite the legal loophole, there is a search for solutions and parameters, which may increase the decomposition of pharmaceutical products present in municipal and industrial effluents in current wastewater treatment systems without influencing the treatment efficiency of other legally defined compounds [14]. Temperature is one of the parameters which influences the removal efficiency of drug substances in biological wastewater treatment plants. A high removal efficiency of contaminants present in wastewater depends on the presence of easily degradable organic compounds and work parameters such as: temperature, wastewater flow rate, chemical composition, age, loading, $\mathrm{pH}$ value, concentration of dissolved oxygen and redox potential. Other significant factors which contribute to improved removal of 
contaminants include SRT (sludge retention time) and HRT (hydraulic retention time). The conditions in specific reaction chambers influence the changes in the microbial community structure in the bioreactors. Wastewater from industrial plants is the biggest challenge for microorganisms due to the high concentration of toxic substances [15]. Larsson's literary analysis shows, that some pharmaceutical companies in Asian countries have a drug concentration (especially antibiotics) even one million times greater than level concentration found in sewage effluents. Such dose levels are toxic to aquatic organisms. These discharges have led to pollution of river sediment, surface, ground and drinking water, also irrigated soils [15]. The interferences and inconsistencies in the activity of activated sludge may also be evaluated based on microscopic observations. Their regular conduct allows to assess e.g. the aeration rate in the aeration chamber, influence of the presence of toxic compounds on activated sludge microorganisms, approximate estimation of contaminant load or causes of foaming in aeration chamber and on the surface of the secondary settling tank. Higher microbial diversity results in more efficient decomposition of various chemical compounds [16]. Among the different groups of drugs currently available on the market, the biological methods of wastewater treatment most efficiently (above $90 \%$ ) eliminate some analgesic drugs (e.g. ibuprofen, aspirin). However antibiotics and hormonal drugs are more problematic, not only due to their resistance to biodegradation even at low concentrations $\left(\right.$ at $\mathrm{ng} / \mathrm{dm}^{3}$ ) but also as a result of changes in cell morphology and functioning of microorganisms in the aquatic environment $[17,18]$.

\section{Influence of temperature and other parameters of ibuprofen reduction rate}

Ibuprofen is susceptible to biodegradation and its efficiency is influenced by varying conditions in the bioreactor, e.g. the temperature. Kujawa-Roeleveld et al. [19] indicate that higher temperature facilitates the ibuprofen decomposition process (at $10{ }^{\circ} \mathrm{C}$ the decomposition occurred at a notably slower rate compared to $20{ }^{\circ} \mathrm{C}$ ). Similar conclusions were confirmed by Kruglova [20] during studies carried out in a sequential biological reactor (SBR) and membrane biological reactor (MBR) at laboratory scale for low temperature ranges. The analysis was conducted at aerobic conditions for two temperature values: 12 and $8{ }^{\circ} \mathrm{C}$. Regardless of the type of bioreactor, the reduction of ibuprofen at higher temperature occurred at a notably higher rate compared to the lower temperature at a given retention time. This confirms the conclusion that geographic location determines the atmospheric conditions and range of average annual temperature values, which significantly influence the development of activated sludge microorganisms in biological wastewater treatment plants. However, studies carried out by Kruglova in SBR at laboratory scale and in an actual wastewater treatment plant in Finland indicate that it is possible to achieve a high ibuprofen reduction rate at $12{ }^{\circ} \mathrm{C}$ by changing other technological parameters e.g. sludge retention time $(S R T)$, redox conditions (anoxic and aerobic), organic loading rate $(O L R)$ [21]. Taking the oxygen concentration into account, the highest reduction rate is achieved at aerobic conditions $(>95 \%$, the biodegradation of ibuprofen to concentrations below the detection limit occurs during two days) [19]. Whereas the ibuprofen removal efficiency at anaerobic conditions reached a maximum of approx. $40 \%$, regardless of the temperature range [22]. The increase of activated sludge age may also result in an increase of removal rate. These conditions are especially advantageous for nitrifying bacteria, since their proliferation is slow. Studies confirm that 
nitrifying bacteria efficiently eliminate e.g. some types of drugs, such as ibuprofen, naproxen, trimethoprim, erythromycin as well as bisphenol A and nonylphenol [23]. Studies carried out by Clara et al. [24] indicate that nitrogen removal at $S R T>10$ days may facilitate the biodegradation efficiency of pharmaceutical compounds, such as ibuprofen, bezafibrate, bisphenol A or natural estrogens. Chen et al. found, that the optimal SRT is within the range of 14-20 days and higher values of this parameter do not improve PPCPs (Pharmaceuticals and Personal Care Products) degradation [25]. The HRT assumed for efficient drug removal from wastewater ranges from 0.5 to 3.0 days [26]. In studies carried out by Prasertkulsak et al. [27] regarding the removal of pharmaceutical residues from wastewater originating from a hospital with the MBR method, it was established that at $H R T$ equal to $3.0 \mathrm{~h}$ most of the pharmaceutical may be efficiently removed.

In case of the removal of acidic pharmaceuticals, which include ibuprofen, the $\mathrm{pH}$ value is the key parameter which influences the drug removal rate. Kimura et al. [28] and Caracciolo et al. [29] reported that the decrease of $\mathrm{pH}$ from 7.0 to 6.0 allows to reduce the concentration of such compounds by up to two times.

The aim of this study was to establish the ibuprofen removal efficiency during a static test with activated sludge depending on the temperature of the process.

\section{Material and methods}

\section{Static test}

The analysis of ibuprofen degradation rate for various temperature values was conducted using a static test, which aimed to verify during a short time period whether the assumed research concept reflects the degradation tendency of this drug and the behaviour of microorganisms in the presence of this toxic substance in relation to wastewater treatment plants at an actual scale.

The static test is a rapid method which allows to verify the assumptions regarding the behaviour of activated sludge subjected to different physicochemical factors, and the obtained results allow to establish conclusions which are helpful for further planning studies of dynamic factors at a larger scale (reference).

The aim of the study was to conduct static tests based on standard PN-C-04645 "Water and wastewater. The study of partial biodegradation of anionic and non-ionic surface active substances. The preliminary test" [29] aimed to initially analyse the changes in the behaviour of activated sludge microorganisms in the presence of ibuprofen for three different temperature values: 8,18 and $28{ }^{\circ} \mathrm{C}$. A pure form of the analgesic drug ibuprofen was used in the studies (Ibuprofen $-\mathrm{C}_{13} \mathrm{H}_{18} \mathrm{O}_{2}(98 \%$ (GC) Pfizer, Sigma Aldrich Co. LLC). The activated sludge used in studies was collected from the aeration chamber of a bioreactor located in the Central Wastewater Treatment Plant in Poznan (Poland), which upon appropriate treatment (intense aeration for $5 \mathrm{~h}$ ) was used as an inoculum $\left(1 \mathrm{~g} / \mathrm{dm}^{3}\right)$ for sterile samples containing the medium and ibuprofen $\left(10 \mathrm{mg} / \mathrm{dm}^{3}\right)$. The prepared samples were placed in an Innova 40R shaker (New Brunswick, Canada). The apparatus was programmed using the following work parameters: different temperature for each sample series $\left(8,18\right.$ or $\left.28{ }^{\circ} \mathrm{C}\right)$ and constant shaking at $150 \mathrm{rpm}$. Each of the samples collected after a given time was subjected to chromatographic analysis in order to determine the ibuprofen concentration with subsequent analysis of its $\mathrm{pH}$ value and chemical oxygen demand (COD). Simultaneously, at the beginning and end of each sample series a qualitative microscopic analysis of activated sludge microorganisms was conducted. 


\section{Sample preparation procedure}

For each three series of samples $1 \mathrm{dm}^{3}$ flasks were prepared two times (a sample at a given time was collected from two identically prepared flasks). Each flask was supplemented with an appropriate amount of activated sludge, to reach a concentration of $1.0 \mathrm{~g}$ of dry matter $/ \mathrm{dm}^{3}$ in each sample, and a dose of ibuprofen was introduced at a concentration of $10 \mathrm{mg} / \mathrm{dm}^{3}$. The established concentration value of ibuprofen is over 1000 times higher than analysed in the natural environment. This value has been chosen for the purpose of checking whether ibuprofen has an inhibitory effect on the vital processes of activated sludge microorganisms. In addition, the concentration value allowed to obtain a reliable result in the chromatographic analysis.

It was assumed that ibuprofen was the only carbon source for the microorganisms, therefore during the first sample series (for one of the three studied temperature values), which lasted for $24 \mathrm{~h}$, no other substrates were introduced into the sample. Next, each prepared sample was filled with distilled water to a final volume of $0.250 \mathrm{dm}^{3}$.

\section{Determination of chemical oxygen demand}

The determination of chemical oxygen demand was conducted in accordance with the Polish Standard PN-ISO 15705:2005 PN-ISO 15705:2005 Water quality. Determination of chemical oxygen demand index (COD). Method miniaturized with the use of gas-tight samples [30].

\section{Determination of ibuprofen content in the wastewater}

The analysis procedure included the separation and concentration of analytes from biodegradation samples by means of solid phase extraction (SPE) and determination using high performance liquid chromatography coupled with tandem mass spectrometry (LC-MS/MS) on an UltiMate 3000 RSLC liquid chromatograph (Dionex, USA) coupled with an API 4000 QTRAP mass spectrometer (Biosystem, MDS Sciex, USA).

Table 1

Optimal performance of MS/MS for ibuprofen

\begin{tabular}{|c|c|c|c|c|c|c|}
\hline Compound & $\begin{array}{c}\text { Pseudo-molecular jon } \\
{[\mathbf{M}-H]^{-}}\end{array}$ & DP [V] & MRM1 & CE [V] & MRM2 & CE [V] \\
\hline Ibuprofen & 205 & -50 & $205 \rightarrow 161$ & -12 & $205 \rightarrow 159$ & -8 \\
\hline
\end{tabular}

A C18 bed $\left(0.006 \mathrm{dm}^{3}, 500 \mathrm{mg}\right.$, J.T. Baker) was used for SPE. Elution of adsorbed analytes was conducted with methanol. Chromatographic separation was conducted using a Hypersil Gold C18 RP column. The mobile phase consisted of an aqueous mixture of $5 \mathrm{mM}$ of ammonium acetate (A) and methanol (B). The analyte was eluted from the column using gradient elution: $0 \min 50 \% \mathrm{~B}, 1 \min 67 \% \mathrm{~B}, 2 \min 67 \% \mathrm{~B}, 3 \min 100 \% \mathrm{~B}, 5 \min$ $100 \%$ B. Next, the flow of the mobile phase was set at $0.0002 \mathrm{dm}^{3} / \mathrm{min}$. Separation was carried out at $35{ }^{\circ} \mathrm{C}$. The volume of the sample introduced into the column was equal to $5 \mu \mathrm{dm}^{3}$. The quantitative analysis was conducted using the MRM operation mode of the mass spectrometer. Electrospray ionisation (ESI) was conducted in negative ion mode. The work conditions for the mass spectrometer were as follows: temperature of ion source at $400{ }^{\circ} \mathrm{C}$, pressure of shielding gas at $138 \mathrm{kPa}(20 \mathrm{psi})$, pressure of nebulising gas at $345 \mathrm{kPa}$ (50 psi), pressure of drying gas at $345 \mathrm{kPa}$, voltage applied to the capillary at 
$4500 \mathrm{~V}$. The monitored ions of studied substances in MRM mode, the declustering potential (DP) as well as collision energy (CE) were shown in Table 1.

MRM1 was used for quantitative analysis of ibuprofen, while MRM2 was used for confirmation of the identification. The loss of ibuprofen during biodegradation was determined using the calibration curve method.

\section{Duration of the test and sampling for analysis}

Each of the three analysed sample series for different temperatures was maintained for $24 \mathrm{~h}$. Three replications for each sample were prepared from two identical flasks. The sample for analysis were designated as follows: blank sample, reference sample (described as "0") which included activated sludge and distilled water, and actual sample (described as "W") which contained activated sludge, distilled water and ibuprofen at the initial concentration $\left(10 \mathrm{mg} / \mathrm{dm}^{3}\right)$. Subsequent samples including activated sludge, distilled water and ibuprofen $\left(10 \mathrm{mg} / \mathrm{dm}^{3}\right)$ were collected after $0.5,1.0,2.0,3.0,4.0,5.0,6.0,7.0$, 8.0 and $24 \mathrm{~h}$. The numeration and description of each sample used as references in the results section are included in Table 2.

Table 2

Designations and description of samples taken for each of the three measurement series, respectively, for each temperature analysed

\begin{tabular}{|c|c|}
\hline Sample designation number & Description of the sample being analysed \\
\hline ,W” & a zero, standard test, containing distilled water and activated sludge \\
\hline „, & $\begin{array}{r}\text { an initial sample containing distilled water, activated sludge and ibuprofen } \\
\text { at a starting concentration of } 10 \mathrm{mg} / \mathrm{dm}^{3}\end{array}$ \\
\hline $\mathbf{1}$ & sample with ibuprofen taken after $0.5 \mathrm{~h}$ \\
\hline $\mathbf{2}$ & sample with ibuprofen taken after $1.0 \mathrm{~h}$ \\
\hline $\mathbf{3}$ & sample with ibuprofen taken after $2.0 \mathrm{~h}$ \\
\hline $\mathbf{4}$ & sample with ibuprofen taken after $3.0 \mathrm{~h}$ \\
\hline $\mathbf{5}$ & sample with ibuprofen taken after $4.0 \mathrm{~h}$ \\
\hline $\mathbf{6}$ & sample with ibuprofen taken after $5.0 \mathrm{~h}$ \\
\hline $\mathbf{7}$ & sample with ibuprofen taken after $6.0 \mathrm{~h}$ \\
\hline $\mathbf{8}$ & sample with ibuprofen taken after $7.0 \mathrm{~h}$ \\
\hline $\mathbf{9}$ & sample with ibuprofen taken after $8.0 \mathrm{~h}$ \\
\hline $\mathbf{1 0}$ & sample with ibuprofen taken after $24.0 \mathrm{~h}$ \\
\hline
\end{tabular}

Prior to commencing the tests as well as after their termination a microscopic analysis was conducted along with the collection of the last sample, which was used for determination of the type and condition of microorganisms present in activated sludge.

\section{Results and discussion}

Figure 1 shows the mean values of $\mathrm{pH}$ shifts during the total testing period i.e. during $24 \mathrm{~h}$ degradation of ibuprofen by activated sludge for each of the 3 sample series at different temperatures: 8,18 and $28{ }^{\circ} \mathrm{C}$. Figure 2 shows the results of percentage reduction of ibuprofen concentration by activated sludge during the study period, i.e. $24 \mathrm{~h}$ for each of the 3 sample series at different temperatures: 8,18 and $28{ }^{\circ} \mathrm{C}$. Figure 3 shows the mean results of COD changing during the study period, i.e. $24 \mathrm{~h}$ for each of the 3 sample series at different temperatures: 8,18 and $28{ }^{\circ} \mathrm{C}$. The decrease $\mathrm{pH}$ in time results from the acidic nature of the initial form of ibuprofen as well as its metabolites. 


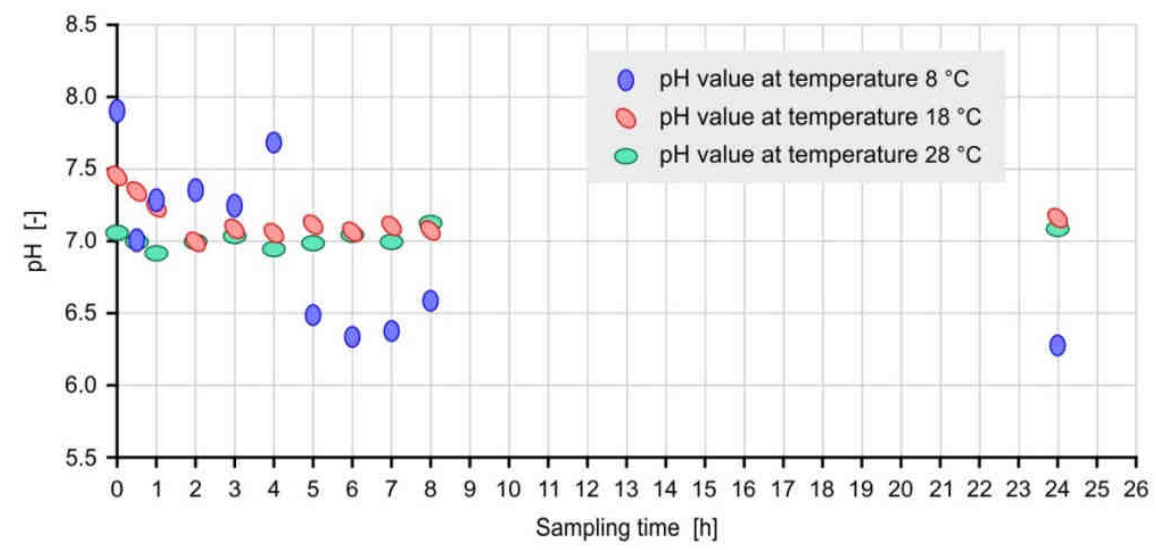

Fig. 1. Mean $\mathrm{pH}$ values obtained for three sample series in relation to changing temperature of the conducted static test

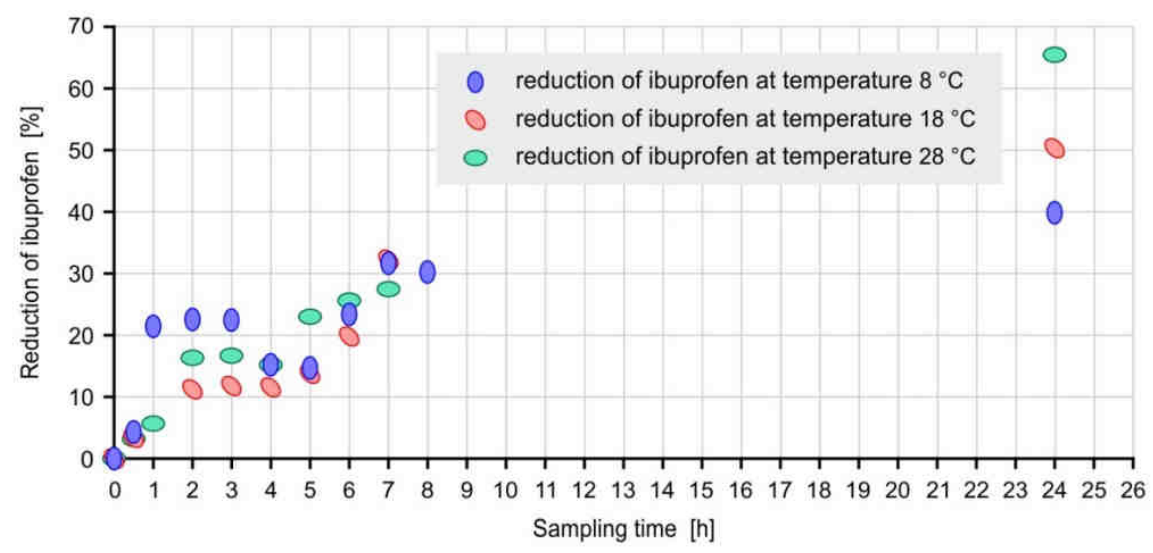

Fig. 2. Reduction of ibuprofen obtained for three sample series in relation to changing temperature of the conducted static test

The results obtained during the static test, which was conducted for $24 \mathrm{~h}$ with three sample series, indicate that the decrease of ibuprofen concentration was depended on the temperature value. At 8 and $18{ }^{\circ} \mathrm{C}$ the concentration of ibuprofen after $24 \mathrm{~h}$ was decreased by $50 \%$, whereas at $28{ }^{\circ} \mathrm{C}$ the analysed drug was degraded by approx. $2 / 3$ in comparison to the initial amount (Fig. 2). At $8{ }^{\circ} \mathrm{C}$ a decrease of $\mathrm{pH}$ from 7.52 to 6.27 along with an increase of ibuprofen retention time was observed for the blank (sample " 0 ") whereas the mean $\mathrm{pH}$ value at 18 and $28{ }^{\circ} \mathrm{C}$ was at approx. 7.0 during the testing period (Fig. 1). In each sample series and for each analysed temperature value a decrease of COD in time was observed (Fig. 3), which indicated that ibuprofen was biodegraded. Microbial analysis was carried out for each of the three sample series. Microscopic analyses were conducted for the initial sample of activated sludge ("W"). Prior to commencing the tests as well as after $24 \mathrm{~h}$ (sample "10"). 


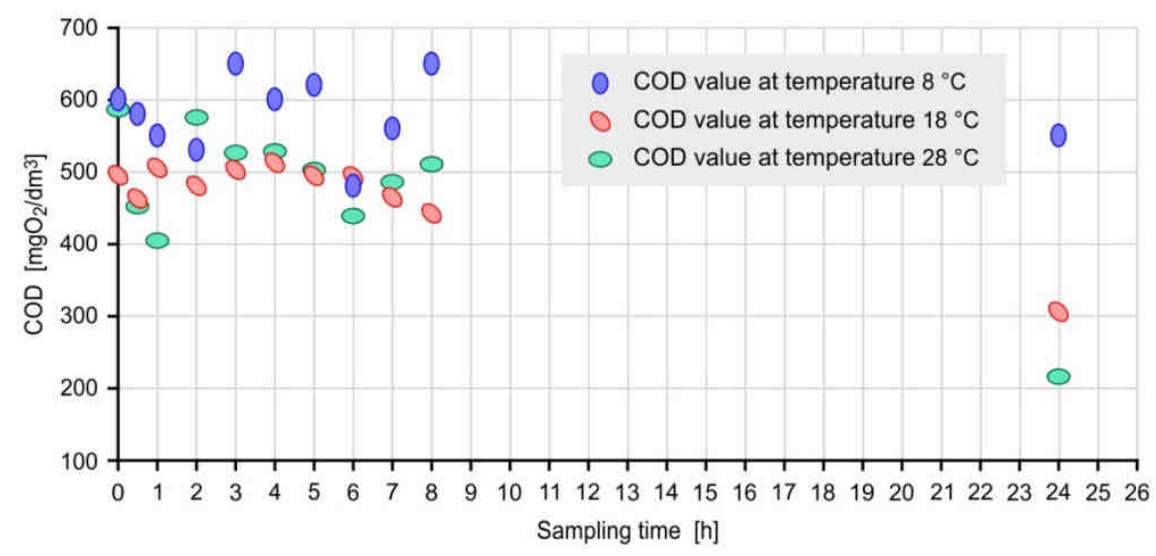

Fig. 3. Mean COD values obtained for three sample series in relation to changing temperature of the conducted static test

The presence of following microorganisms was confirmed in the initial activated sludge sample (,W”): rhizopoda (Rhizopoda): Arcella vulgaris, Amoeba proteus, flagellates (Flagellata): Peranema sp., ciliates (Ciliata): Aspidisca costata, Paramecium caudatum, Paramecium bursaria, Glaucoma scintillans, Litonotus sp., Spirostomum sp., Stylonychia sp., Opercularia coarctata, Carchesium polypinum, Epistylis lacustris, Epistylis plicatilis, Vorticella convallaria, tardigarde (Tardigrada): Tardigrada n.det., nematodes (Nematoda): Nematoda n.det., Rotifer (Rotatoria): Lecane sp., bacteria and filamentous fungi n.det., free-floating bacteria n.det. The activated sludge community was dominated by settled ciliates, additionally bacteria and filamentous fungi were also abundant. The flocks were small but numerous. All organisms were very active, with the lowest activity observed for samples kept at $8{ }^{\circ} \mathrm{C}$. In activated sludge samples after $24 \mathrm{~h}$ (sample "10") it was established that the qualitative and quantitative composition and activity of microorganisms was very similar to the initial sample ("W") directly upon addition of ibuprofen. It was thus observed that ibuprofen at a dose of $10 \mathrm{mg} / \mathrm{dm}^{3}$ did not cause any changes in the composition or activity of activated sludge microorganisms after $24 \mathrm{~h}$. During microscopic observation at the beginning of testing (in the initial sample "W") as well as after $24 \mathrm{~h}$ for each sample series, the presence of settled, creeping and free-floating ciliates, rotifers and amoebas was confirmed. The small size of flocks and the presence of numerous living filamentous bacteria and single nematodes may be caused by the poor overall condition of the sludge (for each of the three sample series the sludge volume index (SVI) was at $\left.>0.900 \mathrm{dm}^{3} / \mathrm{g}\right)$. The observed reduction of ibuprofen concentration and the following decrease of COD may confirm that activated sludge microorganisms actively participated in the degradation of this drug. A lack of an alternative carbon source forced the microorganisms to modify their metabolic processes and adapt them to uptake more complex carbon sources, e.g. ibuprofen.

\section{Conclusions}

The literature analysis and the conducted studies confirmed that ibuprofen removal occurs more rapidly at higher temperature values compared to colder environmental 
conditions. Furthermore, a longer retention time also facilitated the reduction of ibuprofen. After $24 \mathrm{~h}$ a decrease of its concentration by approx. 40 and $50 \%$ (for 8 and $18{ }^{\circ} \mathrm{C}$, respectively) was observed, whereas the highest reduction by approx. $65 \%$ occurred at $28{ }^{\circ} \mathrm{C}$. Ibuprofen is not reduced completely, which may result in its introduction to water reservoirs, which are often a source of drinking water. The increasing consumption and production of drugs is associated with the risk of constant accumulation of their non-metabolized forms in the environment. Therefore, the search for solutions which allow to increase the removal efficiency of pharmaceutical products from wastewater streams are currently a priority challenge in the fight against the contamination of the aquatic environment. Furthermore, the growing social concern indicates that it is more justified to adapt regulations which counter or efficiently limit the transfer of pharmaceuticals into the environment by establishing threshold concentrations for active substances discharged into water reservoirs after treatment of wastewater.

The results obtained during the static test allowed to observe a correlation between the behaviour of activated sludge microorganisms in the dynamic system at an actual scale and the tendency observed at the laboratory scale. The static test confirmed that the reduced percentage of pharmaceutical compounds at higher temperature values is more efficient compared to lower temperatures.

The obtained results suggest that static tests may be helpful for conducting general observations of the behaviour of activated sludge subjected to drug substances, regardless of the differences compared to dynamic systems.

In order to accurately estimate which microorganisms are responsible for the removal of ibuprofen, it would be necessary to carry out studies on the reduction of this drug using cultured pure bacterial strains. Further tests should also check whether the ibuprofen is released into the liquid phase during sludge stabilization.

\section{Acknowledgements}

This work was supported by the Polish Ministry of Science and Higher Education (03/31/SBAD/0379; 01/13/SBAD/0913).

\section{References}

[1] Eslami A, Amini MM, Yazdanbakhsh AR, Rastkari N, Mohseni-Bandpei A, Nasseri S, et al. Environ Monit Assess. 2015;187(12):1-15. DOI: 10.1007/s10661-015-4952-1.

[2] Salgado R, Noronha JP, Oehmen A, Carvalho G, Reis MA. Water Sci Technol. 2010;62(12):2862-2871. DOI: $10.2166 /$ wst.2010.985.

[3] Yu CP, Roh H, Chu KH. Environ Sci Technol. 2007;41:486-492. DOI: 10.1021/es060923f.

[4] Landers TF, Cohen B, Wittum TE, Larson EL. Public Health Rep. 2012;127,1:4-22. DOI: 10.1177/003335491212700103.

[5] Szymonik A, Lach J, Malińska K. Ecol Chem Eng S. 2017;24(1):65-85. DOI: 10.1515/eces-2017-0006.

[6] Langenhoff A, Inderfurth N, Veuskens T, Schraa G, Blokland M, Kujawa-Roeleveld K, et al. BioMed Res Int. 2013:1-9. DOI: 10.1155/2013/325806.

[7] Kosjek T, Heath E, Kompare B. Anal Bioanal Chem. 2007;387(4):1379-1387. DOI: 10.1007/s00216-006-0969-1.

[8] Zając A, Kruszelnicka I, Ginter-Kramarczyk D, Zembrzuska J. Przem Chem. 2016;95:263-268. DOI: 10.15199/62.2016.2.15.

[9] Liu J, Dan X, Lu G, Shen J, Wu D, Yan Z. Ecotoxicol Environ Saf. 2018;15;154:214-220. DOI: 10.1016/j.ecoenv.2018.02.052.

[10] Melvin SD, Cameron MC, Lanctôt CM. J. Toxicol Environ Health A. 2014;77(6): 337-345. DOI: 10.1080/15287394.2013.865107. 
[11] Zuriaga E, Lomba L, German B, Lanuza PM, Aldea L, Ribate MP, et al. Chem Ecol. 2019;35(2):102-114, DOI: $10.1080 / 02757540.2018 .1540608$.

[12] Zhou Y, Wu S, Zhou H, Huang H, Zhao J, Deng Y. Environ Int. 2018;121(1):523-537. DOI: 10.1016/j.envint.2018.09.041.

[13] Directive 2013/39/EU of the European Parliament and of the Council of 12 August 2013 as regards priority substances in the field of water policy. https://eur-lex.europa.eu/legal-content/EN/ TXT/HTML/?uri=CELEX:32013L0039\&from=EN.

[14] Ginter-Kramarczyk D, Zając A, Kruszelnicka I, Zembrzuska J, Budnik I. Przem Chem. 2013;92:596-600.

[15] Larsson DGJ. Philos Trans R Soc B. 2014;369:1-7. DOI:10.1098/rstb.2013.0571.

[16] Cinà P, Bacci G, Arancio W, Gallo G, Fani R, Puglia AM, et al. Bioresour Technol. 2019;282:254-261. DOI: 10.1016/j.biortech.2019.03.018.

[17] Küummerer K. Annual Rev Environ Resour. 2010;35:57-75. DOI: 10.1146/annurev-environ-052809-161223.

[18] Gilbert N. Nature. 2011;476:265. DOI: 10.1038/476265a.

[19] Kujawa-Roeleveld K, Schuman E, Grotenhuis T, Kragić D, Mels A, Zeeman G. Biodegradability of human pharmaceutically active compounds $(\mathrm{PhAC})$ in biological systems treating source separated wastewater streams. Third SWITCH Scientific Meeting, Brazil, 2008. http://www.switchurbanwater.eu/outputs/pdfs/ W41_GEN_RPT_D4.1.3_Biodegradability_and_fate_of_phamarceutical_compounds.pdf.

[20] Kruglova A, Kråkström M, Riska M, Mikola A, Rantanen P, Vahala R. Bioresour Technol. 2016;214:81-88. DOI: 10.1016/j.biortech.2016.04.037.

[21] Kruglova A, Ahlgren P, Korhonen N, Rantanen P, Mikola A, Vahala R. Sci Total Environ. 2014;499:394-401. DOI: 10.1016/j.scitotenv.2014.08.069.

[22] Ebele AJ, Abdallah MAE, Harrad S. Emerg Contam. 2017;3:1-16. DOI: 10.1016/j.emcon.2016.12.004.

[23] Fernandez-Fontaina E, Omil F, Lema JM, Carballa M. Water Res. 2012;46:5434-5444. DOI: 10.1016/j.watres.2012.07.037.

[24] Clara M, Kreuzinger N, Strenn B, Gans O, Kroiss H. Water Res. 2015;39:97-106. DOI: 10.1016/j.watres.2004.08.036.

[25] Chen X, Vollertsen J, Nielsen JL, Dall AG, Bester K. Ecotoxicology. 2015;24:2073-2080. DOI: 10.1007/s10646-015-1548-z.

[26] Falås P, Baillon-Dhumez A, Andersen HR, Ledin A, la Cour Jansen J. Water Res. 2012;46:1167-1175. DOI: 10.1016/j.watres.2011.12.003.

[27] Prasertkulsak S, Chiemchaisri C, Chiemchaisri W, Itonaga T, Yamamoto K. Chemosphere. 2016;150:624-631. DOI: 10.1016/j.chemosphere.2016.01.031.

[28] Kimura K, Hara H, Watanabe Y. Water Sci Technol. 2010;62:1084-1089. DOI: 10.2166/wst.2010.356.

[29] Caracciolo AB, Topp E, Grenni P. J Pharm Biomed Anal. 2015;106:25-36. DOI: 10.1016/j.jpba.2014.11.040.

[30] PN-C-04645. 2001. Woda i ścieki. Badanie biodegradacji częściowej anionowych i niejonowych substancji powierzchniowo czynnych. Test wstępny. (Polish Standard. PN-C-04645:2001. Water and wastewater. The study of partial biodegradation of anionic and non-ionic surface active substances. The preliminary test). http://sklep.pkn.pl/pn-c-04645-2001p.html.

[31] PN-ISO 15705:2005. Jakość wody. Oznaczanie indeksu chemicznego zapotrzebowania tlenu (SP-ChZT). (Polish Standard. PN-ISO 15705:2005 PN-ISO 15705:2005 Water quality. Determination of chemical oxygen demand index (COD). http://sklep.pkn.pl/pn-iso-15705-2005p.html. 